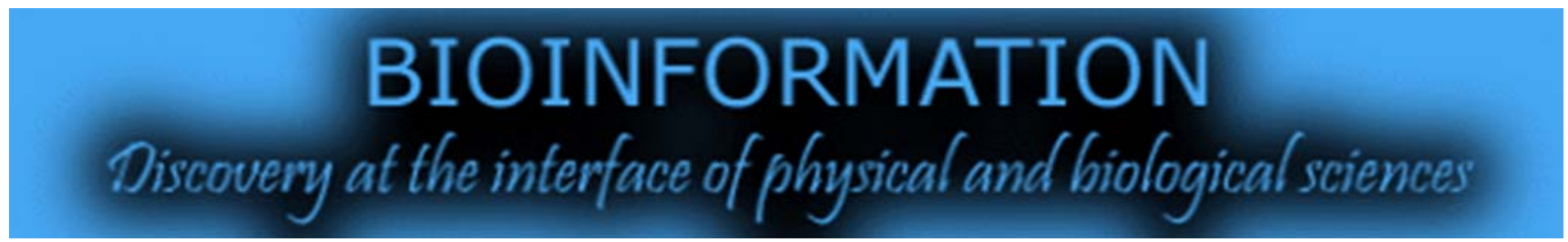

\title{
Gene-chromosome locations of neuropsychiatric diseases
}

\author{
Paul Shapshak ${ }^{1,2} *$, Charurut Somboonwit ${ }^{1,3}$, John Sinnott ${ }^{1,3}$ Deborah Commins $^{4,5}$, Elyse \\ Singer ${ }^{5,6}$, \& Andrew Levine ${ }^{5,6}$
}

\begin{abstract}
1Division of Infectious Disease and International Medicine, Tampa General Hospital, USF Health, Tampa, FL 33601; ${ }^{2}$ Department of Psychiatry \& Behavioral Medicine, University of South Florida, College of Medicine, Tampa, FL 33613; ${ }^{3}$ Clinical Research Unit, Hillsborough Health Department, Tampa, FL 33602; ${ }^{4}$ Department of Pathology, USC Keck School of Medicine, Los Angeles, CA 90089; ${ }^{5}$ National Neurological AIDS Bank, UCLA Geffin School of Medicine, Westwood, CA 90095; ${ }^{6}$ Department of Neurology, UCLA Geffin School of Medicine, Westwood, CA 90095; Paul Shapshak - Email: pshapshak@gmail.com; phone: 843-754-0702; Fax: 813-844-8013; *Corresponding author
\end{abstract}

Received: November 20, 2011; Accepted November 26, 2011; Published December 10, 2011

Availability: http://www.bioinformation.net/007/paul.xls

\begin{abstract}
:
A number of genes are involved in various neuropsychiatric disorders. A comprehensive compilation of these genes is important for a better understanding of these diseases. We report an online file that lists genes by chromosome number and location. This is useful for the rapid examination of chromosome bands for genes involved in these diseases. This is not an exhaustive list and does not include single nucleotide polymorphism (SNP) results for genes that are currently being examined by genome wide association studies (GWAS) and other molecular methodologies.
\end{abstract}

\section{Background:}

It is often of interest for the researcher to ascertain rapidly the location of genes on various human chromosomes. We present a table of genes involved in various neuropsychiatric diseases [1, 2] listed by chromosome number and banding. There is no selection of specific disease category. It should be noted that many diseases (e.g. deafness, Parkinson's disease, epilepsy, etc.) appear at many bands among the chromosomes. Similarly, many bands harbor more than one disease.

\section{Methodology:}

Public databases of genes related to chromosome locations were examined [3-6] Results were tabulated by human chromosome and banding as given in the excel dataset (Please see available URL to download). The gene functions are described in detail in the databases. The information relating to gene locations for neuropsychiatric diseases is readily accessible on these web-sites. The numbers of sites and diseases on each chromosome arm are shown in Table 1 (supplementary material).

Future developments:

The purpose here is to present the chromosome and band locations for genes involved in neuropsychiatric diseases. Several bands are associated with more than one neuropsychiatric disease and will be investigated in future studies. This list does not include genes that currently discovered by recent GWAS and other molecular methodologies. Future reviews of the literature and web sites will examine in detail the large number of newly identified genes with their SNP locations and pathways that 
are involved in these and additional neuropsychiatric diseases.

\section{Acknowledgments:}

We acknowledge the Editors for advice. We acknowledge public website databases at the following institutions: NCBI (Bethesda, MD), OMIM (Bethesda, MD), GeneCards (Rehovoth, Israel), and UCSC (Santa Cruz, CA). We thank Dr. P. Wang at NCBI (Bethesda, MD) for advice in this study. Support for this work included: NIH Grants (PS) DA 14533, DA 12580, GM 056529 and (ES, DC, AJL, PS) 1U01MH083500 and NS 38841. PS also thanks the Division of Infectious Diseases and International Medicine (USF, Tampa, FL) for support. The authors report no conflicts of interest.

\section{References:}

[1] Bradley WG et al., Neurology in Clinical Practice, Butterworth-Heinemann Publ. 6th Ed. 2008 ISBN: 9780-7506-7525-3.

[2] Sadock BJ et al., Comprehensive Text book of Psychiatry, Walters-Kluwer-Lippincott Publ. 9th ed. 2009 ISBN: 978-0-7817-6899-3

[3] http://www.ncbi.nlm.nih.gov/ncbisearch

[4] http://www.ncbi.nlm.nih.gov/omim

[5] http://www.genecards.org/

[6] http://www.ncbi.nlm.gov/pubmed/20959295

Edited by $\mathbf{P}$ Kangueane

Citation: Shapshak et al. Bioinformation 7(7): 366-368 (2011)

License statement: This is an open-access article, which permits unrestricted use, distribution, and reproduction in any medium, for non-commercial purposes, provided the original author and source are credited. 


\section{Supplementary material:}

Table 1: Numbers of sites and diseases on each chromosome.

\begin{tabular}{|c|c|}
\hline Chromosome number and arm & Number of diseases/locations \\
\hline $1 p$ & 30 \\
\hline $1 \mathrm{q}$ & 28 \\
\hline $2 p$ & 14 \\
\hline $2 q$ & 25 \\
\hline $3 p$ & 11 \\
\hline $3 q$ & 12 \\
\hline $4 \mathrm{p}$ & 10 \\
\hline $4 q$ & 15 \\
\hline $5 p$ & 5 \\
\hline $5 q$ & 18 \\
\hline $6 p$ & 20 \\
\hline $6 q$ & 18 \\
\hline $7 \mathrm{p}$ & 3 \\
\hline $7 q$ & 17 \\
\hline $8 p$ & 7 \\
\hline $8 q$ & 14 \\
\hline $9 \mathrm{p}$ & 5 \\
\hline $9 q$ & 14 \\
\hline $10 p$ & 4 \\
\hline $10 \mathrm{q}$ & 17 \\
\hline $11 \mathrm{p}$ & 13 \\
\hline $11 q$ & 12 \\
\hline $12 \mathrm{p}$ & 5 \\
\hline $12 q$ & 14 \\
\hline $13 p$ & - \\
\hline $13 q$ & 20 \\
\hline $14 \mathrm{p}$ & - \\
\hline $14 \mathrm{q}$ & 18 \\
\hline $15 p$ & - \\
\hline $15 q$ & 19 \\
\hline $16 \mathrm{p}$ & 13 \\
\hline $16 q$ & 3 \\
\hline $17 p$ & 8 \\
\hline $17 \mathrm{q}$ & 22 \\
\hline $18 p$ & 5 \\
\hline $18 \mathrm{q}$ & 3 \\
\hline $19 p$ & 14 \\
\hline $19 q$ & 13 \\
\hline $20 p$ & 9 \\
\hline $20 \mathrm{q}$ & 4 \\
\hline $21 p$ & - \\
\hline $21 \mathrm{q}$ & 6 \\
\hline $22 p$ & - \\
\hline $22 q$ & 18 \\
\hline $\mathrm{Xp}$ & 6 \\
\hline$X q$ & 18 \\
\hline
\end{tabular}

